\title{
EXPLORING THE RELATIONSHIPS BETWEEN SATISFACTION, PLACE ATTACHMENT AND LOYALTY IN NIGERIAN ZOOS
}

\author{
Omolola O. AJAYI \\ University of Johannesburg, School of Tourism and Hospitality, College \\ of Business and Economics, South Africa, e-mail: omololaajayioa@gmail.com
}

Tembi M. TICHAAWA*

University of Johannesburg, School of Tourism and Hospitality, College of Business and Economics, South Africa, e-mail: tembit@uj.ac.za

\begin{abstract}
Citation: Ajayi, O.O., Tichaawa, T.M. (2021). EXPLORING THE RELATIONSHIPS BETWEEN SATISFACTION, PLACE ATTACHMENT AND LOYALTY IN NIGERIAN ZOOS. GeoJournal of Tourism and Geosites, 37(3), 861-872. https://doi.org/10.30892/gtg.37317-719
\end{abstract}

\begin{abstract}
Surveys exploring satisfaction, place attachment and loyalty in a zoo context are scarce despite the prevalence of such studies vis a vis other tourism destinations, and their valued importance in understanding travel behaviour and contributions to destinations' success. This study explores the relationships between visitors' satisfaction, place attachment (place identity, place dependence, place affect and place social bonding) and loyalty in one of Nigeria's prominent zoos. This study adoped a qunatitative research approach, with data obtained from a sample of 395 visitors through a structured questionnaire. Using structural equation modeling, we found that the most important causal factor of loyalty is satisfaction, either directly or indirectly through some dimensions of place attachment. In addition, it was revealed that place social bonding can act as either a predictor or an outcome of visitors' satisfaction. Satisfaction was found to be a significant and positive mediator between place attachment (place identity and place social bonding) while place attachment was found not to mediate the relationship between satisfaction and loyalty. The findings were discussed and practical applications were drawn, particularly aimed at optimizing and providing satisfying experiences which enhances place attachment as well as loyalty.
\end{abstract}

Key words: Loyalty, place attachment, satisfaction, travel behaviour, zoo

\section{INTRODUCTION}

Optimizing place attachment, satisfaction and loyalty has become a crucial objective of any tourism destination, and is vital in destination marketing. These behavioural constructs are key to understanding the psychology of visitors' behaviour, and ultimately ensuring the success of a destination. Visiting zoos has remained a popular nature-based tourism activity (WAZA, 2005; Ajayi, 2015; Ajayi and Tichaawa, 2020) that is geared towards the experience of seeing wild animals at close ranges. The goals of zoo keeping have evolved from exclusively serving an amusement and entertainment purpose to accommodating education, recreation, conservation and research purposes (Patrick et al., 2007; Stephanie, 2013). As a result, visitor types have also evolved in order to accommodate individuals who are inclined towards learning, participating in conservation activities, and enjoying outdoor recreation in a sustainable manner. This consequently provides a new dimension to zoo management and marketing practices and introduces a need to ensure visitors' satisfaction, and ultimately place attachment and loyalty. These visitors can only be retained if their needs are met and if their positive experiences are relayed to others (Kotler et al., 2010). Stedman (2002) defined visitor satisfaction as a multifaceted evaluation of a place's felt worth, the level of satisfaction determined by the perception of the physical and social characteristics of an area. When a visitor's experience leads to feelings of fulfilment, the visitor is thus satisfied; when a visitor is displeased with his/her experience, it leads to dissatisfaction (Chen and Chen, 2010). Place attachment in tourism denotes the emotional ties a visitor shares with a tourism destination. This brings about the sense of actually being and feeling 'in place' or 'at home' (Yuksel et al., 2010) - a feeling of conviction and safety (Tsai, 2012). Place attachment has four sub-constructs (Rolero and De Picolli, 2010; Scannell and Gifford, 2010) namely place dependence (attachment to the functional attributes of place), place identity (attachment to place that affirms and enables one's identity), place social bonding (ties to places that encourages social bonding) and place affect (the love for the essence of a place). A common measure of loyalty in this context is the intention for repeat visits by tourists and the likelihood that a travel destination will be recommended to other people (Yoon and Uysal, 2005; Neuts et al., 2013).

Visitors' satisfaction, place attachment and loyalty have been researched extensively as individual variables and have also been assessed in relation to other constructs such as attitudes, perception, image, motivation, emotional solidarity and destination attractiveness. Linkages have often been established between two of the variables such as place attachment and satisfaction (Yuksel et al., 2010; Lee et al., 2012; Prayag and Ryan, 2012; Ramkissoon et al., 2014), place attachment and loyalty (Alshemeili, 2014), and satisfaction and loyalty (Oom et al., 2006; Valle et al., 2006; Hui et al., 2007; Neuts et al., 2013).

\footnotetext{
* Corresponding author
} 
Fewer researches have focused on the interconnectedness of all three variables. Two studies which have, for example, considered all three variables are Yuksel et al. (2010) and Lee et al. (2012) which, using place attachment as a mediating variable, examined these three constructs in a holiday destination and in festival hosting destinations respectively and in so doing, they both established positive associations. The external validity of these findings and applicability to other destination types however has been questioned. In addition, two dimensions of place attachment (place identity and place dependence) were analysed as compared to the four sub-constructs that make up place attachment. Place social bonding and place affect are generally under-researched in place attachment studies (Ramkissoon et al., 2012) while most emphasis has been attributed to place identity and place dependence (Kyle et al., 2004). Using the setting of a zoological garden, for which there exists a dearth of research, this study is focused on determining the extent to which visitors' satisfaction contributes to place attachment (using the four sub-constructs) and vice versa while loyalty serves as the overall outcome variable.

\section{LITERATURE REVIEW}

\section{Visitors' satisfaction}

Visitors' satisfaction, as defined by Thaothampitak and Weerakit (2014), are visitors after-the-act evaluations of the overall service experience. Oliver (1997: 13) defined satisfaction as "a judgment that a product, or service feature, or the product or service itself, provides a pleasurable level of consumption-related fulfilment". Stedman (2002) provides an additional summary of visitor satisfaction as a multifaceted evaluation of a place's felt worth, the level of satisfaction determined by the perception of the physical and social characteristics of an area. When a visitor's experience leads to feelings of fulfilment, then the visitor is satisfied; when they are displeased with their experience, it leads to dissatisfaction (Chen and Chen, 2010). The success of a tourism destination is validated based on the ability to create and sustain visitors' satisfaction (Bosque and Martin, 2008). In tourism literature, there are various approaches to examining satisfaction. One is the expectancy-disconfirmation approach which is a very widespread paradigm (see Yuksel and Yuksel, 2007; Millán and Esteban, 2002) which evaluates satisfaction through a comparative analysis of customers' expectations of a product and service prior to and after consumption (Oliver, 1980). There exists a midpoint referred to as confirmation where the product or service meets expectations. This midpoint is strengthened by disconfirmation where the good or service is evaluated as either beyond (positive disconfirmation) or below expectation (negative disconfirmation).

'Another dimension is the perceived actual performance of a good or service (Tse and Wilton, 1998) which is considered an important tool when measuring satisfaction, especially when the customer has little or no prior knowledge of the experience to form prior-expectations, which is usually the case for tourism products (Yoon and Uysal, 2005). The study of Lee and Beeler (2007) provides empirical evidence that projects the performance measure to be stronger than the expectation-disconfirmation approach. Research (see Ajayi, 2019; Kozak, 2001; Yu and Goulden, 2006) has also evolved to include the assessment of the individual performances of tangible and intangible elements of a destination via the satisfaction of the customers with the elements. The performance-only approach has also been used in assessing the overall visitors' satisfaction with a destination. This connotes the sum of the feelings that visitors have about their tourism experience (Tian-Cole et al., 2002) and can be seen in studies of Ajayi (2019), Kozak (2001), Qu and Ping (1999), and Yu and Goulden (2006). This study employs the perceived actual performance approach.

Satisfaction has been largely examined as an outcome linked to service quality, expectation, perceptions, motivations (Mellina and Aballe, 2013; Thaothampitak and Weerakit, 2014; Alarape et al., 2015; Philemon, 2015) and as a determinant of loyalty (Bigne et al., 2005; Lee et al., 2011; Ajayi, 2019). It is common thinking that the satisfaction of visitors is a viable determinant of two key aspects: their future intentions, such as with their consumption of tourism products and choice of destination (Lee et al., 2012); and of their societal and political support (Tonge et al., 2011). Most significantly, a satisfying experience usually leads to loyalty, and in a few studies, it has been assessed as a predictor of behavioural constructs such as place attachment (Ramkissoon et al., 2012; Sıvalıoğlu and Berkoz, 2012).

\section{Place Attachment}

First used within the discourse of geography, place attachment connotes the affinity people have for their sociotemporal spaces like the home, communities and societies. This construct was then later studied in environmental psychology, architecture and has over time been adapted to recreation studies, and applied most especially to outdoor events like hiking (Kyle et al., 2003) and rafting (Bricker and Kerstetter, 2000). The scope of the term has increased to accommodate adults' social interactions, other social settings and places (Morgan, 2010; Wiles et al., 2009), and in this case, tourism destinations. Place attachment is multifaceted and is comprised of four sub-constructs, namely place dependence, place identity, place affect and place social bonding. In tourism studies, the first two are the most prominent and sometimes projected as the most important dimensions. This study explores all four of the dimensions of place attachment. Place dependence referes to the functional ties to a place's physical and unique attributes, which contributes to the visitation goal of the visitors (Scannell and Gifford 2010). Yuksel et al. (2010) suggested that people usually assess places against available alternatives in response to the satisfaction of a need. In a zoo setting, the physical attributes could include the diversity of animals, the presence of mega-vertebrates, visitors centre, tour guides, landscape, etc. Place affect is one of the most under-researched components of place attachment. Place affect descibes the affective feeling an individual develops with a place (Rolero and De Picolli, 2010) which brings about a sense of psychological well-being for the individual (Brown et al., 2003) and generates sentiments about the place (Kyle et al., 2004). Places that provide recreational experiences to people (such as zoos) aids the psychological well being of the visitors, and as scuh, possibly increases positive feelings and ties with such places (Hinds and Sparks, 2008). 
Place identity occurs when an individual connects their values to that which is projected by a place. Budruk et al. (2009) defined it as the connection between an individual's personal identity and a place - the place enables the person to both affirm and express their identity. For example, zoos that are actively involved in education and conservation practices, may attract and retain conservation-minded visitors. Visitors who demonstrate great place identity typically exhibit place protective behaviours (Stedman, 2002). Place social bonding, another under-researched construct in tourism studies, refers to the ties that an individual develops with places that encourage and foster interpersonal and group engagements (Hammitt et al., 2006; Scannell and Gifford, 2010). The social bonding opportunities that such places provide is equally if not more valuable than their physical characteristics (Cooper-Marcus, 1992) and can thus serve as a key attraction factor for such areas (Kyle et al., 2004). This is the case with zoos since they offer avenues for social gatherings and interactions - it has often been observed that visitors to zoos generally come in tour groups, as families (parents with children), as a group of friends etc (Ajayi, 2019). In literature, place attachment has been treated as an outcome in itself which is predicted by other constructs such as images, attitudes and motivation (Lime and Costen, 2011; Gross and Brown, 2008; Ajayi, 2019); a predictor of other outcomes such as satisfaction and responsible behaviour (Ramkissoon et al., 2012; Cheng et al., 2013; Ramkissoon et al., 2014; Woosnam et al., 2016) and as a mediator between variables such as attitudes, expectations, image, destination attractiveness, satisfaction and loyalty (Yuksel et al., 2010; Lee et al., 2011; Qiu, 2014). The dimensions of place attachment have been demonstrated to influence behavioral outcomes such as loyalty in differing ways, and that this also varies across various destinations, consumer characteristics, activity involvement and more (see Kyle et al., 2004, 2005; Lee et al., 2011).

\section{Loyalty}

Loyalty, as described by Oliver (1997), is a deep obligation to patronise or buy a much liked service or product continuously, hence resulting in having a constant trademark, in spite of situations and circumstances and defiling market factors that can influence a change. A common definition for loyalty is the intention for repeat visits by tourists and the likelihood of recommendation to friends or family (Yoon and Uysal, 2005; Neuts et al., 2013).

Similarly, Lovelock (2011:11) defined it as "willingness to continue patronizing a business over a long term, purchasing and using its goods and services on a repeated and preferably exclusive basis and voluntarily recommending the firm's products to friends and associates". Studies have shown that loyalty is multidimensional and there continues to be a debate on the most important dimensions. Three dimensions of loyalty have been identified: the attitudinal approach, the behavioural approach and the composite approach (the least common approach of the three) (Zhang et al., 2014; Afthanorhan et al., 2019). The attitudinal approach is based on customers' intentions to buy a product or on brand preferences (Yoon and Uysal, 2005). It is a psychological commitment to purchase a good or service (Iwasaki and Havitz, 1998). Hence, tourists may exhibit a good disposition towards visiting a destination (Bastic and Gojcic, 2011). The attitudinal approach provides a way to understand the reasons why customers purchase a product or service, with the goal of understanding their preferences and attitudes over time (Lee et al., 2012). The attitudinal approach is the most evaluated approach to loyalty in tourism literature, and it is the approach adopted in this study.

The behavioural approach is the sequence of purchase and patronage made by the customer (Backman and Crompton, 1991). It focuses on the actual repeat purchases made rather than the reasons which underlie the purchase (Lee et al., 2012). Some of the measures of behavioural loyalty include: the rate of purchase of a particular product or service to the total purchase of products in the same group; history of use or purchase; time devoted to purchasing the product daily, weekly, monthly or yearly, and number of purchase, use or participation (Iwasaki and Havitz, 1998). According to Oppermann (2000), the ease of obtaining information on consumers repeat purchase history makes it a common measure. Its applicability in the tourism context has been questioned however, as the determination of a time frame for re-patronage of tourists' products and services are largely undefined (Michels and Bowen, 2005; Oppermann, 2000). The composite approach is the combination of both attitudinal and behavioural approaches (Backman and Crompton, 1991).

\section{Satisfaction and place attachment}

While satisfaction and place attachment has been employed in wide range of management issues, few empirical pieces of evidence on the relationship between the two exist (Lee et al., 2012). More so, the reports of these studies vary greatly. For example, the studies of Mesch and Manor (1998), and Lee and Allen (1999) established no relationship between the two constructs. Mesch and Manor (1998) particularly noted that a person may be satisfied with their homes or communities without developing a certain attachment to them. Conversely, some studies (Brocato, 2006; George and George, 2004; Petrick et al., 1999) have established that satisfaction with a particular setting brings about an emotional affinity which illustrates that satisfaction is a predictor of place attachment.

In seeking to understand the relationship between satisfaction and place attachment, some studies treat place attachment as a first order construct, while others consider it as a second order construct. Halphenny (2010), for example, considered place attachment as a first order construct and reported a significant relationship between satisfaction and place attachment. As a second order construct, Alexandris et al. (2006) observed that, in a ski resort in Greece, "personal interaction quality" was a stronger predictor of place identity than was "physical environmental quality," whereas the effect of "physical environmental quality" on place dependence was stronger than that of personal interaction quality. The study of Lee et al. (2012) revealed that festival satisfaction was a significant predictor of place identity/social bonding as well as place dependence. The variance explained was however higher for place dependence than for place identity, making satisfaction a better predictor of place dependence. Other studies that have outlined that satisfaction is a predictor of place attachment 
include Yuksel et al. (2010), Prayag and Ryan (2012), Tsai (2012), Chen and Phou (2013), Sivalığlu and Berkoz (2016) however all of these studies were conducted outside of the zoo context. Based on this, it is therefore hypothesized that visitors' satisfaction will positively influence the four dimensions of place attachment, as well as overall place attachment.

$\mathrm{H}_{\mathrm{o}}$ 1: Visitors satisfaction contributes significantly to place attachment

$\mathrm{H}_{\mathrm{o}} 1 \mathrm{a}$ : Visitors satisfaction contributes significantly to place dependence

$\mathrm{H}_{\mathrm{o}} 1 \mathrm{~b}$ : Visitors satisfaction contributes significantly to place identity

$\mathrm{H}_{\mathrm{o}} 1 \mathrm{c}$ : Visitors satisfaction contributes significantly to place affect

$\mathrm{H}_{\mathrm{o}} 1 \mathrm{~d}$ : Visitors satisfaction contributes significantly to place social bonding

Studies such as Hwang et al. (2005), and Prayag and Ryan (2012) indicated that place attachment could in fact predict satisfaction. This was affirmed for place dependence, place affect and place social bonding by Ramkissoon et al. (2013) in an Australian national park. Similarly, Campon-Cerro et al. (2015) in their study in rural tourism destinations revealed that place identity and dependence predicts satisfaction, with the latter having more influence. Based on the foregoing, the earlier hypotheses were reversed so as to establish the specific pattern of relationship between place attachment and satisfaction as follows:

$\mathrm{H}_{\mathrm{o}}$ 2: Place attachment contributes significantly to visitors' satisfaction

$\mathrm{H}_{\mathrm{o}} 2 \mathrm{a}$ : Place dependence contributes significantly to visitors' satisfaction

$\mathrm{H}_{\mathrm{o}} 2 \mathrm{~b}$ : Place identity contributes significantly to visitors' satisfaction

$\mathrm{H}_{0}$ 2c: Place affect contributes significantly to visitors' satisfaction

$\mathrm{H}_{\mathrm{o}} 2 \mathrm{~d}$ : Place social bonding contributes significantly to visitors' satisfaction

\section{Satisfaction and loyalty}

The relationship between satisfaction and loyalty has been explored widely in the available literature with various results across difference settings. On the other hand, in an international tourism context, Oppermann (1999) opined that there might not be a relationship between the two constructs. This was additionally argued by Michels and Bowen (2005) that while visitors may be satisfied with the destination visited and the various activities in which they participated, repeat visitation may be unforeseeable especially given constraints of travel expenses, time available for leisure, and the presence of other alternative destinations within the host region. Putting this in perspective, some visitors go to certain destinations when they visit family and friends or attend conferences and other events therefore such visits may not be regular given its location outside the original state or region of the visitor, and as such, visitors who may have been satisfied with their visit may have no opportunities to demonstrate behavioural loyalty, even if attitudinal loyalty is assured. On the other hand, several studies have indeed found a relationship between satisfaction and loyalty (See Neuts et al., 2013; Huang et al., 2015; Petrick, 2004; Lee et al., 2007; Lee et al., 2014; Campon-Cerro et al., 2015; Wang and Hsu, 2010; Chen and Tsai, 2007; Prayag and Ryan, 2012, Nasir et al., 2020, Butler, 2016). Despite the fact that all of these studies were researched outside of the zoo context, based on their findings, we posit that:

\section{$\mathrm{H}_{\mathrm{o}} 3$ : Satisfaction contributes significantly to visitors' loyalty}

\section{Place attachment and loyalty}

Place attachment was demonstrated as an antecedent of loyalty by Yuksel et al. (2010). It was reported that three sub-constructs of place attachment (place dependence, place identity and place affect) directly influenced loyalty. In addition, Lee et al. (2012) observed that place identity/social bonding was a positive predictor of revisit intentions, while place dependence was a negative predictor. Similarly, in their study of rural tourism destinations, Campon-Cerro et al. (2015) found that place identity and dependence predicts satisfaction, with the latter having more influence.

Patwardhan et al. (2020), in a religious tourism context, reported place dependence as a stronger predictor of satisfaction than place identity. When evaluating the relationship between place attachment and return visits to a heritage site and treating three aspects of place attachment (place identity, place dependence and emotional affinity/place affect) as a composite, Alshemeili (2014) found a positive and significant relationship between the two. Isa et al. (2020), in their study of the effect of place attachment on revisit intentions to an Island in Indonesia, established a significant association. The most important dimension of place attachment in predicting revisit intention was place social bonding. Other studies have also been carried out by Nasir et al. (2020), Alexandris et al. (2006), Loureiro (2014), Tsai (2016), $\mathrm{Xu}$ and Zhang (2016), Liu et al. (2017) and Butler (2016). Based on this research, we, therefore, hypothesize that:

$\mathrm{H}_{\mathrm{o}} 4$ : Overall place attachment significantly influences visitors' loyalty

$\mathrm{H}_{\mathrm{o}} 4 \mathrm{a}$ : Place dependence contributes significantly to visitors' loyalty

$\mathrm{H}_{\mathrm{o}} 4 \mathrm{~b}$ : Place identity contributes significantly to visitors' loyalty

$\mathrm{H}_{\mathrm{o}} 4 \mathrm{c}$ : Place affect contributes significantly to visitors' loyalty

$\mathrm{H}_{\mathrm{o}} 4 \mathrm{~d}$ : Place social bonding contributes significantly to visitors' loyalty

\section{Satisfaction, place attachment and loyalty}

Recently, place attachment has been suggested to be a product of satisfactory place experiences which hitherto positively influence loyalty (Halpenny, 2010; Lee et al., 2007). However, very few empirical studies have been carried out examining the relationship between these three behavioural constructs. Lee et al. (2012) in a festival setting 
examined the mediating effect of place attachment on the relationship between satisfaction and loyalty. It was reported that satisfied visitors had a moderate level of emotional attachment to the destination, and as such, developed loyalty, thus establishing the mediating effect of place attachment on satisfaction and loyalty. With respect to the dimensions, a positive indirect effect was recorded for place identity/social bonding while a negative one was documented for place dependence. In addition, Yuksel et al. (2010) reported that three sub-constructs of place attachment (place dependence, place identity and place affect) influenced loyalty directly and indirectly through satisfaction. The study by CamponCerro et al. (2015) revealed that destination identity and dependence mediates the relationship between overall satisfaction and loyalty to rural tourism destinations, but that destination dependence has a greater influence.

$\mathrm{H}_{\mathrm{o}}$ 5: Place attachment mediates the relationship between satisfaction and loyalty

$\mathrm{H}_{\mathrm{o}}$ 5a: Place dependence mediates the relationship between satisfaction and loyalty

$\mathrm{H}_{\mathrm{o}} 5$ b: Place identity mediates the relationship between satisfaction and loyalty

$\mathrm{H}_{\mathrm{o}} 5 \mathrm{c}$ : Place affect mediates the relationship between satisfaction and loyalty

$\mathrm{H}_{\mathrm{o}} 5 \mathrm{~d}$ : Place social bonding mediates the relationship between satisfaction and loyalty

Yuksel et al. (2010) and Prayag and Ryan (2012) however also verified the mediating effect of overall satisfaction between place attachment and loyalty/behavioural intention, measured through re-visitation and recommendations. Accordingly, it is hypothesized that visitors' functional, emblematic, affective and social attachments to zoo settings arise from satisfactory experiences, which ultimately leads to their loyalty towards the destination.

\section{$\mathrm{H}_{\mathrm{o}} 6$ : Visitors satisfaction mediates the relationship between place attachment and loyalty \\ $\mathrm{H}_{\mathrm{o}} 6 \mathrm{a}$ : Satisfaction mediates the relationship between place dependence and loyalty \\ $\mathrm{H}_{\mathrm{o}} 6 \mathrm{~b}$ : Satisfaction mediates the relationship between place identity and loyalty \\ $\mathrm{H}_{\mathrm{o}} 6 \mathrm{c}$ : Satisfaction mediates the relationship between place affect and loyalty \\ $\mathrm{H}_{\mathrm{o}} 6 \mathrm{~d}$ : Satisfaction mediates the relationship between place social bonding and loyalty}

\section{METHODOLOGY}

Visitors to the University of Ibadan Zoological Garden, one of the most prominent zoos in the southwest region of Nigeria, were surveyed. The zoo is located within Nigeria's premier University along the Department of Zoology, and is managed by the institution for recreation, educational and research purposes. The zoo attracts thousands of visitors annually who experience its diverse collection of animals in a serene environment. It has basic recreational facilities for adults and children. This study employs a quantitative research approach. Data was collected between June and December 2018 at the three resting points within the zoo (the central point opposite the ostrich enclosure; the resting point opposite the primates' enclosure and the entry/exit collection point opposite the small birds' enclosures). Data was collected on both weekdays and weekends in order to reach a diverse range of respondents, as it was observed that lone visitors, school groups (excursions), and few friends group visit during weekdays while family and friends across various age groups visited mostly on the weekends. Most visitors surveyed were approached after they had completed the zoo tour, and were more relaxed, which was assumed to increase their willingness to participate. The researcher also served as a tour guide to some visitors, which enabled them to be more relaxed and enhanced their willingness to participate in the study. The aim of the study was explained to all the visitors. Purposively, visitors of at least 18 years of age were surveyed. In total, 395 visitors were sampled which was determined using Yamane formula for sample size determination from a known population. Data was collected through the use of a structured questionnaire in order to elicit information on visitors' place attachment, satisfaction and loyalty. The place attachment scale was adapted from the studies of Kyle et al. (2004), Gross and Brown (2008) and Scannell and Gifford (2010). Satisfaction and loyalty scales were modified from Oliver (1997) and Huh (2002). These scales were scored on a five point likert scale of strongly disagree (1) to strongly agree (5). All analyses were carried out using Smart Pls version 3.0 software using Structural Equation Modeling.

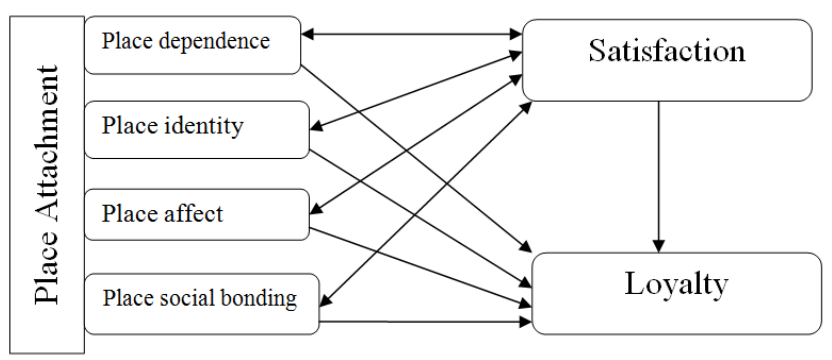

Figure 1. The Study's Conceptual Model

\section{RESULTS}

\section{Descriptive results}

The visitors displayed high levels of satisfaction (4.43) and loyalty (4.41). Among the place attachment scales, place social bonding had the highest score (3.62). The scores of place affect, place identity and place dependence were $3.03,2.87$ and 2.77 respectively. This is presented in Table 1.

\section{Measurement model}

\section{Individual factor analysis}

As illustrated in Table 1, factor loadings of most of the items (ranging from 0.528 to 0.965 ) were above the 0.50 threshold recommended by Bagozzi and Yi (1988) and Cabrera-Nguyen (2010) and were also significant at p<0.05 except for items PA5, PA12, PA14, PA15. These exceptional items were excluded from further analysis. 
Table 1. Confirmatory factor analysis of dimensions and items

\begin{tabular}{|c|c|c|c|c|c|c|}
\hline & Factors & Mean & $\begin{array}{l}\text { Factor } \\
\text { loading }\end{array}$ & $\begin{array}{c}\text { Cronbach } \\
\text { alpha }\end{array}$ & $\begin{array}{c}\text { Composite } \\
\text { reliability }\end{array}$ & $\begin{array}{c}\text { Average variance } \\
\text { extracted }\end{array}$ \\
\hline & Place attachment & 3.07 & & 0.806 & 0.820 & \\
\hline & Place identity & 2.87 & & 0.901 & 0.918 & 0.739 \\
\hline PA1 & I feel this zoo is part of me & 2.84 & 0.924 & & & \\
\hline PA2 & I identify strongly with this zoo & 2.79 & 0.921 & & & \\
\hline PA3 & I have a strong sense of belonging to this zoo & 2.90 & 0.875 & & & \\
\hline \multirow[t]{2}{*}{ PA4 } & Visiting this zoo says a lot about who I am & 2.97 & 0.698 & & & \\
\hline & Place dependence & 2.77 & & 0.818 & 0.831 & 0.629 \\
\hline PA5 & $\begin{array}{l}\text { For what I like to do, I could not imagine anything better than the } \\
\text { settings and facilities provided by this zoo }\end{array}$ & 2.77 & $0.109 *$ & & & \\
\hline PA6 & $\begin{array}{l}\text { For the activities I enjoy the most, the settings and facilities provided } \\
\text { by this zoo are the best }\end{array}$ & 2.75 & 0.575 & & & \\
\hline PA7 & I enjoy visiting this zoo more than any other zoo / nature attractions & 2.57 & 0.827 & & & \\
\hline \multirow[t]{2}{*}{ PA8 } & No other place can substitute for the attractions of this zoo & 2.98 & 0.789 & & & \\
\hline & Place Affect & 3.03 & & 0.872 & 0.873 & 0.699 \\
\hline PA9 & I am very attached to this zoo & 2.99 & 0.787 & & & \\
\hline PA10 & I feel a strong sense of belonging to this zoo and its settings/facilities & 3.11 & 0.664 & & & \\
\hline PA11 & This zoo means a lot to me & 2.91 & 0.965 & & & \\
\hline \multirow[t]{2}{*}{ PA12 } & I have a special connection to the people who visit here. & 3.18 & $0.493 *$ & & & \\
\hline & Place Social Bonding & 3.62 & & 0.771 & 0.672 & 0.525 \\
\hline PA13 & $\begin{array}{l}\text { Many of my friends/family prefer this zoo over many other wildlife } \\
\text { attractions }\end{array}$ & 3.88 & 0.528 & & & \\
\hline PA14 & $\begin{array}{l}\text { If I were to stop visiting this zoo, I would lose contact with a number } \\
\text { of friends }\end{array}$ & 2.80 & $0.317 *$ & & & \\
\hline PA15 & $\begin{array}{l}\text { My friends/family would be disappointed if I were to start visiting } \\
\text { other settings and facilities }\end{array}$ & 3.69 & $0.229 *$ & & & \\
\hline \multirow[t]{2}{*}{ PA16 } & I prefer to visit this attraction with people who are important to me & 4.11 & 0.867 & & & \\
\hline & Satisfaction & 4.43 & & 0.852 & 0.910 & 0.771 \\
\hline SAT1 & I believe I did the right thing when I chose to visit this zoo & 4.45 & 0.894 & & & \\
\hline SAT2 & The overall sight and impression of the zoo inspired me & 4.38 & 0.882 & & & \\
\hline \multirow[t]{2}{*}{ SAT3 } & I am satisfied with my experience in this zoo & 4.29 & 0.859 & & & \\
\hline & Loyalty & 4.40 & & 0.803 & 0.910 & 0.835 \\
\hline LOY1 & I will recommend this zoo to others & 4.41 & 0.917 & & & \\
\hline LOY2 & I will visit this zoo again & 4.39 & 0.911 & & & \\
\hline
\end{tabular}

\section{Test of reliability and validity}

The test of reliability was first evaluated using the Cronbach alpha $(\alpha)$. As shown in Table 1, the $\alpha$ of the behavioural constructs measured (ranging from 0.711 to 0.901 ) was above 0.70 , thus indicating that there were internal consistencies and that the factors could adequately measure the latent variable (Hair et al., 1998, 2010).

In addition, composite validity for all the constructs was greater than 0.60 , which is an indicator of good reliability of the constructs (Fornell and Larcker, 1981). The validity of the scales was first measured using the average variance extracted (AVE), and it was found that all values were above 0.5. This depicts convergent validity, according to Fornell and Larcker (1981) and Anderson and Gerbing (1988). Given these findings, the convergent validity of the scales was established. Furthermore, discriminant validity was evaluated by comparing the square roots of the AVES for each construct with correlations across the factors. As presented in Table 2, the figures were lower than the square root of the AVES, thus representing that the constructs are independent of each other.

Table 2. Inter-construct correlations for discriminant validity

\begin{tabular}{|l|c|c|c|c|c|c|}
\hline & Loyalty & $\begin{array}{c}\text { Place } \\
\text { affect }\end{array}$ & $\begin{array}{c}\text { Place } \\
\text { dependence }\end{array}$ & $\begin{array}{c}\text { Place } \\
\text { identity }\end{array}$ & $\begin{array}{c}\text { Place social } \\
\text { bonding }\end{array}$ & Satisfaction \\
\hline Loyalty & 0.914 & & & & & \\
\hline Place affect & 0.101 & 0.836 & & & & \\
\hline $\begin{array}{l}\text { Place } \\
\text { dependence }\end{array}$ & 0.092 & 0.583 & 0.793 & & & \\
\hline Place identity & -0.167 & 0.633 & 0.414 & 0.859 & & \\
\hline $\begin{array}{l}\text { Place social } \\
\text { bonding }\end{array}$ & 0.230 & 0.286 & 0.307 & 0.159 & 0.724 & \\
\hline Satisfaction & 0.795 & 0.098 & 0.140 & -0.088 & 0.270 & 0.878 \\
\hline
\end{tabular}

\section{Results of Hypothesis 2}

As indicated in Table 3, two dimensions of place attachment significantly influenced visitors' satisfaction, place identity $(\beta=-0.269, \mathrm{t}=2.435, \mathrm{p}=0.015)$ and place social bonding $(\beta=0.240, \mathrm{t}=4.712, \mathrm{p}=0.000)$, and accounted for

\section{Structural model}

Results of Hypothesis 1

As indicated in Table 3, visitors' satisfaction significantly influenced only one dimension of place attachment, place social bonding $(\beta=$ $0.255, \mathrm{t}=5.054, \mathrm{p}=0.000)$, and accounted for $7.5 \%$ of the variance. Place identity, place dependence and place affect were found to not be significantly influenced by satisfaction at $\mathrm{p}>$ 0.05 . Overall place attachment to the zoo was additionally insignificantly influenced by satisfaction at $\mathrm{p}>0.05$. 
$1.0 \%$ and $7.6 \%$ variance respectively. While the prior exerts a negative influence, in which an increase in visitors place identity will correspond to low visitors satisfaction, the latter projects a positive influence where an increase in place social bonding values of the visitors translates to higher visitors satisfaction. Place dependence and place affect, despite having positive estimates, did not significantly influence satisfaction at $\mathrm{p}>0.05$. Overall, visitors' satisfaction with zoo experience was not significantly influenced by place attachment at $\mathrm{p}>0.05$.

\section{Results of Hypothesis 3}

The results in Table 3 reveale that visitors satisfaction significantly predicts loyalty $(\beta$ $=0.773, \mathrm{t}=25.449, \mathrm{p}=0.000$ ). This result shows that the path of visitors' satisfaction in the zoo to loyalty was direct and positive, accounting for $65.5 \%$ variance. Thus, an increase in their satisfaction translates to a stronger level of loyalty to the zoo.

\section{Results of Hypothesis 4}

As shown in Table 3, the loyalty of visitors to the zoo was significantly influenced by place identity $(\beta=-0.188, \mathrm{t}=3.101, \mathrm{p}=$ 0.002 ) explaining only $3.1 \%$ of variance and place social bonding $(\beta=0.134, \mathrm{t}=2.264, \mathrm{p}=0.027)$ accounting for $5.5 \%$ variance. Other dimensions and overall place attachment had no significant contributions at $\mathrm{p}>0.05$.

\section{Test of Hypotheses 5 and 6}

The test of mediating place attachment in the relationship between visitors' satisfaction and loyalty revealed that none of the dimensions of place attachment was a significant mediator between satisfaction and loyalty at $\mathrm{p}>0.05$ (Table 4). Therefore, hypothesis 5 was not supported. On the other hand, place identity $(\beta=-0.2 .14, \mathrm{t}=$ 2.406, $\mathrm{p}=0.016)$ and place social bonding $(\beta=0.191, \mathrm{t}=4.692, \mathrm{p}=$ 0.000 ) were found to significantly

mediate the relationship between satisfaction and loyalty. While the effect of the prior is negative, that of the latter is positive (Table 5). Overall, it was also found that satisfaction is a significant and positive mediator between place attachment and loyalty $(\beta=0.031, \mathrm{t}=2.368, \mathrm{p}=0.018)$. Thus, hypothesis 6 is supported.

\section{DISCUSSION}

This study examined the relationships among satisfaction, place attachment and loyalty in one of the foremost zoos in Nigeria. Six key findings were reported. Firstly, this study found that, out of the four sub-constructs of place attachment examined, visitors' satisfaction contributed significantly to only place social bonding. Zoos are spaces for social gathering and interaction (Chris and Jan, 2004; Smith et al., 2012; Ajayi, 2019) and foster family and friends' wildlife experiences in a close-up environment. It was observed that visitors to the zoo came, learned, toured and entertained themselves in groups, while lone visitors sought out interactions with other people. This study projects satisfaction as an antecedent of place social bonding. This was also reported by Lee et al. (2012) and Ramkissoon et al. (2014) who found positive associations between place social bonding and satisfaction amongst festival attendees and national park visitors, respectively. The better and more satisfying the social experiences of these visitors in the zoo, the higher their attachment to the zoo for social bonding. Arguably, the highest-ranked factor on the place social bonding scale was the factor 'I prefer to visit this attraction with people who are important to me'. Other sub-constructs; place 
identity, place dependence and place affect were not significantly influenced by satisfaction, neither was this significant with respect to overall place attachment. This suggests that place attachment is better measured through its subconstructs in order to determine the contributions of each rather than as a unidimensional construct.

Secondly, two dimensions of place attachment were found to significantly influence visitors' satisfaction: place identity and place social bonding. Whereas place identity was found to exert a negative influence, in which an increase in visitors' place identity did not correspond to improved visitors satisfaction, place social bonding projects a positive influence. This result could suggest that individuals who find a connection between their personal identity and a place, in this case a zoo, do not depict their satisfaction; rather their satisfaction may be enhanced by other factors, or that their purpose of visit was not for identification with the place visited. This finding contradicts Campon-Cerro et al. (2015) who documented place identity as a significant and positive predictor of satisfaction in a rural tourism destination context. With respect to place social bonding, the findings suggest that visitors experience greater satisfaction when they are able to establish social bonding values or find the zoo as that which fosters kinship interactions. This is in line with the study of Ramkissoon et al. (2013) in a national park setting and serves to reiterate the fact that most zoo visits are group

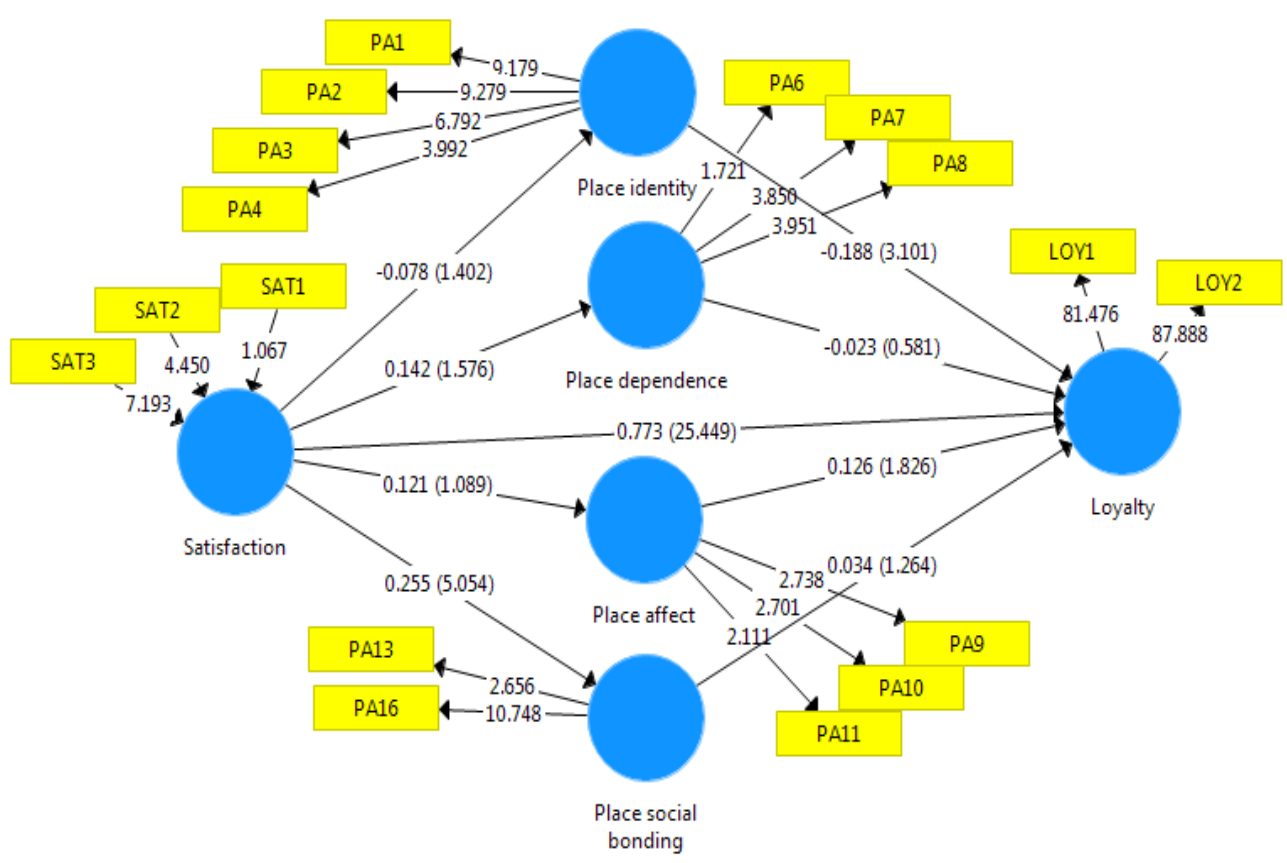

Figure 2. Structural model for Satisfaction - place attachment --Loyalty model

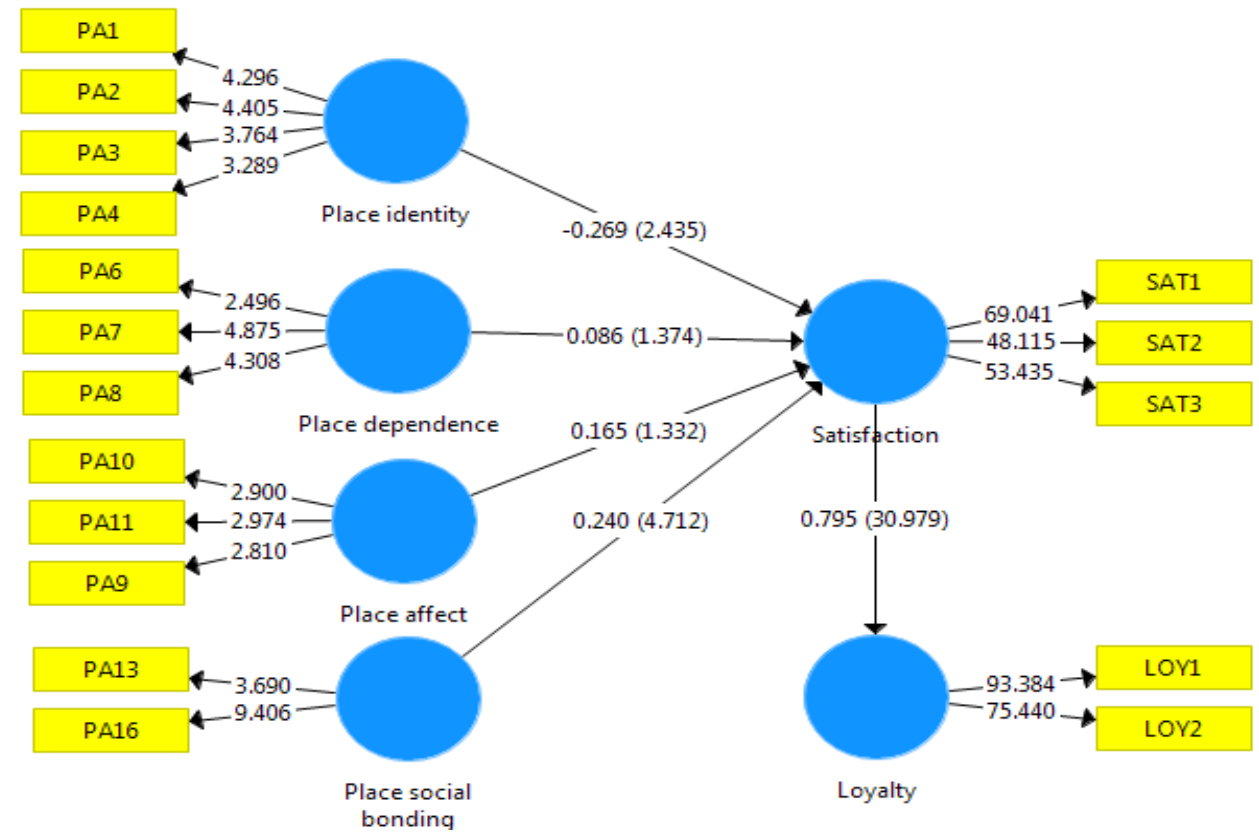

Figure 3. Structural model for place attachment - Satisfaction - Loyalty model

visits, and as such, visitors seeks social interactions in such environment. With respect to overall place attachment, there was no significant association found. Hitherto, the findings are consistent with Yuksel et al. (2010) and Prayag and Ryan (2012) in that place attachment, through its dimensions, can predict visitors' satisfaction.

Thirdly, it was revealed that the higher the satisfaction of visitors, the greater, better and more positive their loyalty will be. This points to the fact that the management of the destination should continually seek to provide genuine and satisfying experiences for their visitors as this will ultimately bring about loyalty. Loyalty in this study was examined based on two key variables: the likelihood of re-visitation to the destination in the nearest future; and the word of mouth recommendation of the zoo to other people. These are indices of patronage, which promote the destination and increase levels of visitation. This finding supports satisfaction as an antecedent and strong predictor of loyalty in a captive wildlife environment and as such, correlates with many previous studies in various settings such as Ajayi et al. (2017), Butler (2016), Campon-Cerro et al. (2015), Chen and Tsai (2007), Huang et al. (2015), Lee et al. (2012), Nasir et al. (2020), Neuts et al. (2013), Petrick (2004), Prayag and Ryan (2012), Sivalıoğlu and Berkoz (2012) and Wang and Hsu (2010). Fourthly, in line with CamponCerro et al. (2015); Lee et al. (2012) and Yuksel et al. (2010), visitors' loyalty was predicted by two place attachment 
sub-constructs: place identity and place social bonding. Place identity was found to have a direct negative effect while place social bonding had a direct positive effect. The negative effect on place identity contradicts that which has been found in previous studies. This finding suggests that for visitors who are able to identify with the zoo or who see the zoo as projecting their values, their re-visitation and/or word of mouth promotion is not guaranteed.

Therefore, the more visitors are able to identify with the zoo, the lower their loyalty while the more they are able to place values on the social interactions enabled therein, the greater their loyalty. Visitors are more willing to come for a re-experience of such meaningful interactions and to spread positive word of mouth recommendations to other people for this reason. Lee et al. (2012) similarily recorded this in their study for place identity/social bonding in a national park. Isa et al. (2020) also identified that the most important dimension of place attachment in predicting revisit intention is place social bonding. Place dependence and place affect had no significant contributions.

In most studies (see Campon-Cerro et al., 2015, Lee et al., 2012, Patwardhan et al., 2020), place dependence has been on the frontline of the predictor of satisfaction or loyalty, followed by place identity in various contexts, however, this study projects place social bonding as the most important place attachment construct in a zoo setting. Finally, place attachment was found to be an insignificant mediator of satisfaction and loyalty. This contradicts Lee et al. (2012) who documented place attachment as a significant mediator of both constructs. Rather, in the study, satisfaction was found to be a significant and positive mediator between place attachment (place identity and place social bonding) and loyalty. Place social bonding was a better and stronger mediator than place identity.

This finding reveals that satisfaction with zoo experiences not only directly enhances the loyalty of the visitors to the zoo but also indirectly enhance loyalty through place attachment, especially through its social bonding dimension. The findings of this study also revealed that place attachment is better measured as a second order construct, consisting of its sub-constructs, rather than as a unidimensional variable which concurs with Ramkissoon et al. (2014).

\section{CONCLUSION}

This study sought to understand the relationships that exist between satisfaction, place attachment and loyalty. The key findings of this study are as follows: (a) the most important causal factor of loyalty is satisfaction, either directly or indirectly through place attachment, especially place social bonding; (b) place social bonding is important in zoo settings, and can act as either a predictor or an outcome of visitors' satisfaction, thus the greater the satisfaction of the visitors, the greater their social bonding to the zoo; and that the more visitors consider the destination as an avenue for social interactions, the greater their satisfaction; (c) place social bonding was the only positive predictor of loyalty, hence, the greater the attachment of visitors to the zoo, vis a vis social bonding, the greater their revisit intentions and willingness to recommend the destination to others; (d) visitors identification with zoos' values does not necessarily correspond to satisfaction or loyalty, and finally, (e) satisfaction was a significant and positive mediator between place attachment (place identity and place social bonding) and loyalty, with place social bonding being a better and stronger mediator than place identity, and place attachment did not mediate the relationship between satisfaction and loyalty.

The SEM model explored highlights the importance of visitors' satisfaction in mediating place attachment and loyalty. It is paramount therefore that managers of the zoo and other destinations should pay attention to increasing and sustaining resources and facilities that provide visitors with a genuinely satisfying experience. The development of increased place attachment and loyalty should also be targeted, especially harbouring on enhancing better place social bonding. According to findings, the real need of visitors seems to be centred on social interactions in an educational and recreational space, hence the provision and investment in facilities and services that encourage this is pertinent for sustained loyalty. The marketing activities of the zoo and other similar destinations should also be centred on attracting this visitors' niche, and discounts and other incentives can be offered in order to encourage frequent and group visitations. The findings are also deemed to be valuable to tourism practitioners, management and regulatory bodies, through reflections on the maintenance of existing facilities as well as the development of innovative product and service designs that facilitate social interactions, and can trigger a social bonding revisit effect. This study makes a significant contribution to literature for the following reasons: it provides empirical evidence on satisfaction, place attachment and loyalty and their inter-relationships in the much scarce zoo-tourism context; it generates two dimensional models by which satisfaction and place attachment are presented as mediators of loyalty while measuring the direct and indirect effects to understand the most profound direction and comparative outlook; it treats place attachment as a second order construct as well as a one-dimensional construct, and it examines four sub-constructs of place attachment rather than just the two that are common in extant studies.

Through these approaches taken in this study, the findings of various other studies, especially with regards to travel behaviour, are also advanced. While this study provides invaluable insights into the relationships between the three constructs, especially to zoos, some limitations should be considered when contextualizing the results. This research was conducted using one zoo as a case study area and additional researches are thus needed in other zoos and ex-situ conservation destinations to allow for generalization across the destinations. Additionally, it may be pertinent in future studies, that satisfaction is explored based on various characteristics of the zoo in order to know emphatically the resources and attributes that can better facilitate visitors place attachment and loyalty. More studies are also needed in order to understand the inverse relationship between place identity and satisfaction, as well as with loyalty in the contexts of zoos.

\section{REFERENCES}

Afthanorhan, A., Awang, Z., Rashid, N., Foziah, H., \& Ghazali, P. (2019). Assessing theeffects of service quality on customer satisfaction. Management Science Letters, 9(1), 13-24. 10.5267/j.msl.2018.11.004 
Ajayi, O.O. (2015). Ecotourism and environmental management: Case study of Okomu National Park and Ogba Zoo \& Nature Park. Masters thesis, University of Ibadan, Nigeria. pp 157.

Ajayi, O.O. (2019). Environmental attitudes, motivation and place attachment of visitors to federal institutionalized zoological gardens in the South-west, Nigeria. PhD thesis, University of Ibadan, Nigeria. pp 385

Ajayi, O.O., Bello Y.O., \& Ayodele, I.A. (2017). Zoo-tourism in Nigeria: Ogba Zoo and Nature Park in perspective. International Journal of Tourism and Hospitality Management, 1(2), 93-109.

Ajayi, O.O., \& Tichaawa, T.M. (2020). Visitorse characteristics and destination image: The case of nigerian zoos. GeoJournal of Tourism and Geosites, 32(4), 1410-1417. https://doi.org/10.30892/gtg.32432-588

Alarape, A.A., Yager, G.O., \& Salman, K.K. (2015). Assessment of tourists satisfaction and perception in Makurdi Zoological Garden, Benue State, Nigeria. Journal of Research in Forestry, Wildlife and Environment, 7(1), 1-12.

Alexandris, K., Kouthouris, C., \& Meligdis, A. (2006). Increasing customers' loyalty in a skiing resort: The contribution of place attachment and service quality. International Journal of Contemporary Hospitality Management, 18(5), 414-425. https://doi.org/10.1108/09596110610673547

Alshemeili, A. (2014). The relationship between place attachment and return visits to heritage sites: A case study of Ras Al Khaimah. Doctoral Thesis, Edith Cowan University.

Anderson, J.C., \& Gerbing, D.W. (1988). Structural equation modeling in practice: A review and recommended two-step approach. Psychological Bulletin, 103(3), 411-23. https://doi.org/10.1037/0033-2909.103.3.411

Backman, S.J., \& Crompton, J.L. (1991). The usefulness of selected variables for predicting activity loyalty. Leisure Science, 13, 205220. https://doi.org/10.1080/01490409109513138

Bagozzi, R.P., \& Yi, Y. (1988). On the evaluation of structure equation models. Academy of Marketing Science, 16(1), 76-94. https://doi.org/10.1007/BF02723327

Bastic, M., \& Gojcic, S. (2011). The ecological motivation of tourists as a determinant of the tourists loyalty. Croatian Operational Research Review, 2, 14-22. https://hrcak.srce.hr/96604

Bigne, J.E., Andreu, L., \& Gnoth, J. (2005). The Theme Park experience: An analysis of pleasure, arousal and satisfaction. Tourism Management, 26(6), 833-844. https://doi.org/10.1016/j.tourman.2004.05.006

Bosque, I., \& Martin, H. (2008). Tourist satisfaction: A cognitive-affective model. Annals of Tourism Research, 35(2), 551-573. https://doi.org/10.1016/j.annals.2008.02.006

Bricker, K.S., \& Kerstetter, D.L. (2000). Level of specialization and place attachment: An exploratory study of whitewater recreationists. Leisure Sciences, 22, 233-257. https://doi.org/10.1080/01490409950202285

Brocato, E. (2006). Place attachment: An investigation of environments and outcomes in service context. Doctoral thesis, The University of Texas at Arlington, Texas, USA.

Brown, B., Perkins, D.D., \& Brown, G. (2003). Place attachment in a revitalizing neighbourhood: Individual and block levels of analysis. Journal of Environmental Psychology, 23(3), 259-271. https://doi.org/10.1016/S0272-4944(02)00117-2

Budruk, M., Thomas, H., \& Tyrrell, T. (2009). Urban green spaces: A study of place attachment andenvironmental attitudes in India.Society and Natural Resources,22(9), 824-839. https://doi:10.1080/08941920802628515

Butler, J.E. (2016). Predicting loyalty in clubs through motivation, perceived value, satisfaction, and place attachment. Doctoral Dissertation, Iowa State University, USA.

Cabrera-Nguyen, P. (2010). Author guidelines for reporting scale development and validation results. Journal of the Society for Social Work and Research, 1(2), 99-103.

Campon-Cerro, A.M., Alves, H.M.B., \& Hernandez-Mogollon, J.M. (2015). Attachment as a factor generating satisfaction with, and loyalty to, rural tourism destinations. Tourism Management, 11(1), 70-76.

Chen, C., \& Chen, F. (2010). Experience quality, perceived value, satisfaction and behavioural intentions for heritage tourists. Tourism Management, 31(1), 29-35. https://doi.org/10.1016/j.tourman.2009.02.008

Chen, C., \& Phou, S. (2013). A closer look at destination: Image, personality, relationship and loyalty. Tourism Management, 36, 269278. https://doi.org/10.1016/j.tourman.2012.11.015

Chen, C., \& Tsai, D. (2007). How destination image and evaluative factors affect behavioral intentions. Tourism Management, 28(4), 1115-1122. https://doi.org/10.1016/j.tourman.2006.07.007

Cheng, T.M., Wu, H.C., \& Hunag, L.M. (2013). The influence of place attachment on the relationship between destination attractiveness and environmentally responsible behaviour for island tourism in Penghu, Taiwan. Journal of Sustainable Tourism, 21(8), 1166-1187. https://doi.org/10.1080/09669582.2012.750329

Chris, R., \& Jan, S. (2004). The zoo as ecotourism attraction - visitor reactions, perceptions and management implications: The case of Hamilton Zoo, New Zealand. Journal of Sustainable Tourism Publication, 12(3), 245-267. https://doi.org/10.1080/09669580408667236

Cooper-Marcus, C. (1992). Environmental memories. In I. Altmanand \& S. Low (Eds.), Place attachment, 87-112, Plenum Press, New York.

Fornell, C., \& Larcker, D.F. (1981). Evaluating structural equation models with unobservable and measurement error. Journal of Marketing Research, 18(3), 39-50. https://doi.org/10.1177/002224378101800104

George, B.P., \& George, B.P. (2004). Past visit and the intention to revisit a destination: Place attachment as a mediator and novelty seeking as the moderator. Journal of Tourism Studies, 15(2), 51-66.

Gross, M., \& Brown, G. (2008). An empirical structural model of tourists and places: Progressing involvement and place attachment in to tourism. Tourism Management, 29(6), 1141-1151. https://doi.org/10.1016/j.tourman.2008.02.009

Hair, J.F., Anderson, R.E., Tatham, R.L., \& Black, W.C. (1998). Multivariate data analysis. Prentice Hall, London, UK.

Hair, J., Black, W., Babin, B., \& Anderson, R. (2010). Multivariate data analysis: A global perspective (7th ed.). Pearson International, London, UK.

Halpenny, E. (2010). Pro-environmental behaviors and park visitors: The effect of place attachment. Journal of Environmental Psychology, 30(4), 409-421. https://doi.org/10.1016/j.jenvp.2010.04.006

Hammitt, W.E., Backlund, E.A., \& Bixler, R.D. (2006). Place bonding for recreational places: Conceptual and empirical development. Leisure Studies, 25(1), 17-41. https://doi.org/10.1080/02614360500098100

Hinds, J., \& Sparks, P. (2008). Engagingwith the natural environment: The role of affective connection and identity. Journal of Environmental Psychology, 28, 109-120. https://doi.org/10.1016/j.jenvp.2007.11.001

Huang, S., Shen, Y., \& Choi, C. (2015). The effects of motivation, satisfaction and perceived value on tourist recommendation. Tourism Travel and Research Association: Advancing Tourism Research Globally. Paper 5. http://scholarworks.umass.edu/ttra/ttra2015/Student_Colloquium/5 
Huh, J. (2002). Tourist satisfaction with cultural/heritage site: The Virginia Triangle, M.Sc, Thesis presented to the faculty of Virginia polytechnic Institute and State University :http://www.scholar.lib.vt.edu/thesis/available/etd-0154002-1710/unrestrited/thesis.pdf.

Hui, T., Wan, D., \& Ho, A. (2007). Tourists' satisfaction, recommendation and revisiting Singapore. Tourism Management, 28, 965-975. https://doi.org/10.1016/j.tourman.2006.08.008

Hwang, S.N., Lee, C., \& Chen, H.J. (2005). The relationship among tourists' involvement, place attachment and interpretation satisfaction in Taiwan's national parks. Tourism Management, 26, 143-156. https://doi.org/10.1016/j.tourman.2003.11.006

Isa, S.M., Ariyanto, H.H., \& Kiumarsi, S. (2019). The effect of place attachment on visitors' revisit intentions: Evidence from Batan. Tourism Geographies, 22(1), 51-82. https://doi.org/10.1080/14616688.2019.1618902

Iwasaki, Y., \& Havitz, M.E. (1998). A path analytic model of the relationships between involvement, psychological commitment, and loyalty. Journal of Leisure Research, 30(2), 256-280. https://doi.org/10.1080/00222216.1998.11949829

Kotler, P., Bowen, J.T., \& Makens, J.C. (2010). Marketing for Hospitality and Tourism (5th ed.). Pearson Education, Upper Saddle River, NJ.

Kozak, M. (2001). Repeaters' Behavior at Two Distinct Destinations. Annals of Tourism Research, 28(3), 785-808. https://doi.org/10.1016/S0160-7383(00)00078-5

Kyle, G., Bricker, K.S., Graefe, A., \& Wickham, T. (2004). An examination of recreationists' relationships with activities and settings. Leisure Sciences, 26(2), 123-142. https://doi.org/10.1080/01490400490432019

Kyle, G., Graefe, A., Manning, R., \& Bacon, J. (2003). An examination of the relationships

between leisure activity involvement and place attachment among hikers along the Appalachian Trail. Journal of Leisure Research, 35(3), 249-273. https://doi.org/10.1080/00222216.2003.11949993

Lee, C., \& Allen, L. (1999). Understanding individuals' attachment to selected destinations: An application of place attachment. Tourism Analysis, 4(3/4), 173-185.

Lee, J., \& Beeler, C. (2007). The relationships among quality, satisfaction, and future intentions for first-time and repeat visitors in a festival setting. Event Management, 10, 197-208. 10.3727/152599507783948684

Lee, J., Graefe, A.R., \& Burns, R.C. (2007). Examining the antecedents of destination loyalty in a forest setting. Leisure Studies, 29, 463481. https://doi.org/10.1080/01490400701544634

Lee, S., Jeon, S., \& Kim, D. (2011). The impact of tour quality and tourist satisfaction on tourist loyalty: The case of Chinese tourists in Korea. Tourism Management, 32, 1115-1124. https://doi.org/10.1016/j.tourman.2010.09.016

Lee, J., Kyle, G., \& Scott, D. (2012). The mediating effect of place attachment on the relationship between festival satisfaction and loyalty to the festival hosting destination. Journal of Travel Research, 51(6), 754-767. https://doi.org/10.1177/0047287512437859

Lime, N., \& Costen, W. (2011). Environmental attitudes, motivation, and attachment: Toward a model of nature-based tourism. International CHRIE Conference-Refereed Track. Event 5 http://scholarworks.umass.edu/refereed/ICHRIE_2011/Wednesday/5

Liu, X., Li, J., \& Kim, W.G. (2017). The role of travel experience in the structural relationships among tourists' perceived image, satisfaction, and behavioral intentions. Tourism and Hospitality Research, 17(2), 135-146. https://doi.org/10.1177/1467358415610371

Loureiro, S.M.C. (2014). The role of the rural tourism experience economy in place attachment and behavioral intentions. International Journal of Hospitality Management, 40, 1-9. https://doi.org/10.1016/j.ijhm.2014.02.010

Lovelock, C. (2011). Service Marketing: People, Technology, Strategy (4th ed.). Prentice Hall, Upper Saddle River, NJ.

Mellina, F.K.M., \& Abale, A.F.A. (2013). Satisfaction on tourists destinations in Davao del Sur. International Journal of Accounting and Business Management, 1(2), 7-17.

Mesch, G.S., \& Manor, O. (1998). Social ties, environmental perception and local attachment. Environment and Behavior, 30(4), 504519. https://doi.org/10.1177/001391659803000405

Michels, N., \& Bowen, J. (2005). The relevance of retail loyalty strategy and practice for leisure/tourism. Journal of Vacation Marketing, 11(1), 5-19. https://doi.org/10.1177/1356766705050839

Millán, Á., \& Esteban, A. (2004). Development of a multiple- item scale for measuring customer satisfaction in travel agencies services. Tourism Management, 25(5), 533-546. https://doi.org/10.1016/j.tourman.2003.07.002

Morgan, P. (2010). Towards a developmental theory of place attachment. Journal of Environmental Psychology, 30, 11-22. https://doi.org/10.1016/j.jenvp.2009.07.001

Nasir, M.N.M., Mohamad, M., Ghani, N.I.A., \& Afthanorhan, A. (2020). Testing mediation roles of place attachment and tourist satisfaction on destination attractiveness and destination loyalty relationship using phantom approach. Management Science Letters, 10, 443-454. https://doi.org/10.5267/j.msl.2019.8.026

Neuts, B., Romao J., van Leeuwen E., \& Nijkamp, P. (2013). Describing the relationships between tourist satisfaction and destination loyalty in a segmented and digitalized market. TI 2013-164/III Tinbergen Institute Discussion Paper. http://www.tinbergen.nl

Oliver, R.L. (1980). A cognitive model of the antecedents and consequences of satisfaction decisions. Journal of Marketing Research, 17(4), 460-469. https://doi.org/10.2307/3150499

Oliver, R.L. (1997). Satisfaction: A behavioral perspective on the consumer. Irwin/McGraw- Hill, New York, USA.

Oom, P., Silva, J., Mendes, J., \& Guerreiro, M. (2006). Tourist satisfaction and destination loyalty intention: A structural and categorical analysis. International Journal of Business Science and Applied Management, 1(1), 26-44. https://doi.org/10.1201/b12231-7

Oppermann, M. (1999). Destination threshold potential and the law of repeat visitation. Journal of Travel Research, 37(2), 131-137. https://doi.org/10.1177/004728759803700204

Oppermann, M. (2000). Tourism destination loyalty. Journal of Travel Research, 39(1), 78-84. https://doi.org/10.1177/004728750003900110

Patrick, P.G., Matthew, C.E., Ayers, D.F., \& Tunnicliffe, S.D. (2007). Conservation and education: Prominent themes in zoo mission statements. The Journal of Environmental Education, 38(3), 53-60. https://doi.org/10.3200/JOEE.38.3.53-60

Patwardhan, V., Ribeiro, M.A., Payini, V., Woosnam, K.M., Mallya, J., \& Gopalakrishman, P. (2020). Visitors place attachment and destination loyalty: Examining the roles of emotional solidarity and perceived safety. Journal of Travel Research, 59(1), 3-21. https://doi.org/10.1177/0047287518824157

Petrick, J. (2004). The roles of quality, value, and satisfaction in predicting cruise passengers' behavioural intentions. Journal of Travel Research, 42(4), 397-407. https://doi.org/10.1177/0047287504263037

Petrick, J., Backman, S., \& Bixler, R. (1999). An investigation of selected factors' impact on golfers' impact on golfer satisfaction and perceived value. Journal of Park and Recreatio Administration, 17(1), 40-59.

Philemon, J.R.M. (2015). Assessment of tourists perception and satisfaction of Tanzania destination. European Scientific Journal, 11(13), 7-15. 
Prayag, G., \& Ryan, C. (2012). Antecedents of tourists' loyalty to Mauritius: The role and influence of destination image, place attachment, personal involvement and satisfaction. Journal of Travel Research, 51(3), 342-356. https://doi.org/10.1177/0047287511410321

Qiu, H.L. (2014). Impact of tourist destination image on place attachment and tourist loyalty. Computer Modelling \& New Technologies, 18(11), 651-656.

Qu, H., \& Ping, E. (1999). A service performance model of Hong Kong cruise travelers' motivation factors and satisfaction. Tourism Management, 20(2), 237-244. https://doi.org/10.1016/S0261-5177(98)00073-9

Ramkissoon, H., Smith, L., \& Kneebone, S. (2014). Visitor satisfaction and place attachment in National Parks. Tourism Analysis, 19, 287-300. 10.3727/108354214X14029467968402

Ramkissoon, H., Weiler, B., \& Graham, L.D. (2012). Place attachment and pro-environmental behaviour in national parks: The development of a conceptual framework. Journal of Sustainable Tourism, 20(2), 257-276. https://doi.org/10.1080/09669582.2011.602194

Ramkissoon, H., Weiler, B., \& Smith, L. (2013). Place attachment, place satisfaction and proenvironmental behaviour: A comparative assessment of multiple regression and structural equation modelling. Journal of Policy Research in Tourism, Leisure \& Events, 5(3), 215-232. https://doi.org/10.1080/19407963.2013.776371

Rolero, C., \& De Picolli, N. (2010). Place attachment, identification and environment perception: An empirical study. Journal of Environmental Psychology, 30, 198-205. https://doi.org/10.1016/j.jenvp.2009.12.003

Scannell, L., \& Gifford, R. (2010). Defining place attachment: A tripartite organizing framework. Journal of Environmental Psychology, 30(1), 1-10. https://doi.org/10.1016/j.jenvp.2009.09.006

Sivalığlu, P., \& Berkoz, L. (2012). Perceptual evaluation of the national park users. Procedia - Social and Behavioral Sciences, 50, 928940. https://doi.org/10.1016/j.sbspro.2012.08.094

Sivalığlu, P., \& Berkoz, L. (2016). Relationship between place attachment and user satisfaction at some national parks in Turkey. ITU $A \mid Z, 13(1), 171-181$. https://doi.org/ 10.5505/itujfa.2016.03522

Smith, L., Weiler, B., Smith, A., \& van Dijk, P. (2012). Applying visitor preference criteria to choose pro-wildlife behaviors to ask of zoo visitors. Curator, 55, 453-466. https://doi.org/10.1111/j.2151-6952.2012.00168.x

Stedman, R.C. (2002). Toward a social psychology of place: Predicting behavior from place-based cognitions, attitudes, and identity. Environment and Behavior, 34(5), 561-581. https://doi.org/10.1177/0013916502034005001

Stephanie, M. (2013). The evolution of zoos. https://ladyofthezoos.com/2013/06/15/the-evolution-of-zoo/ [Accesed 17 January, 2017].

Thaothampitak, W., \& Weerakit, N. (2014). Tourist motivation and satisfaction: The case study of Trang Province, Thailand. Prince of Songkla University, Thailand.

Tian-Cole, S., Crompton, J.L., \& Willson, V.L. (2002). An empirical investigation of the relationships between service quality, satisfaction and behavioral intentions among visitors to a wildlife refuge. Journal of Leisure Research, 34(1), 1-24. https://doi.org/10.1080/00222216.2002.11949957

Tonge, J., Moore, S.A., \& Taplin, R. (2011). Visitor satisfaction analysis as a tool for parkmanagers: A review and case stud y. Annals of Leisure Research, 14(4), 289-303. https://doi.org/10.1080/11745398.2011.639339

Tsai, C.T. (2016). Memorable tourist experiences and place attachment when consuming local food. International Journal of Tourism Research, 18(6), 536-548. https://doi.org/10.1002/jtr.2070

Tsai, S.P. (2012). Place attachment and tourism marketing: Investigating international tourists in Singapore. International Journal of Tourism Research, 14, 139-152. https://doi.org/10.1002/jtr.842

Tse, D.K., \& Wilton, P.C. (1988). Models of consumer satisfaction: An extension. Journal of Marketing Research, 25(2), $204-212$. https://doi.org/10.2307/3172652

Valle, O.D., Silva, S.A., Mendu, J., \& Guerreco, M. (2006). Tourist satisfaction and destination loyalty intention: Structural and categorical analysis. International Journal of Business Science and Applied Management, 1(1), 25-44.

Wang, C.Y., \& Hsu, M.K. (2010). The relationships of destination image, satisfaction, and

behavioral intentions: An integrated model. Journal of Travel \& Tourism Marketing, 27(8), 829-843. https://doi.org/10.1080/10548408.2010.527249

Wiles, J.L., Allen, R.E.S., Palmer, A.J., Hayman, K.J., Keeling, S., \& Kerse, N. (2009). Older people and their social spaces: A study of well-being and attachment to place in Aotearoa New Zealand. Social Science and Medicine, 78, 664-671. https://doi.org/110.1016/j.socscimed.2008.11.030

Woosnam, K.M., Aleshinloye, K.D., Strzelecka, M., \& Erul, E. (2016). The role of place attachment in developing emotional solidarity with residents. Journal of Hospitality \& Tourism Research, 42(7), 1058-1066. https://doi.org/10.1177/1096348016671396

$\mathrm{Xu}, \mathrm{Z}$., \& Zhang, J. (2016). Antecedents and consequences of place attachment: A comparison of Chinese and Western urban tourists in Hangzhou, China. Journal of Destination Marketing \& Management, 5(2), 86-96. https://doi.org/10.1016/j.jdmm.2015.11.003

Yoon, Y., \& Uysal, M. (2005). An Examination of the effects of motivation and satisfaction on destination loyalty: A structural model. Tourism Management, 26(1), 45-56. https://doi.org/10.1016/j.tourman.2003.08.016

Yu, L., \& Goulden, M. (2006). A comparative analysis of international tourists' satisfaction in Mongolia. Tourism Management, 27(6), 1331-1342. https://doi.org/10.1016/j.tourman.2005.06.003

Yuksel, A., \& Yuksel., F. (2007). Shopping risk perceptions: Effects on tourists' emotions, satisfaction and expressed loyalt intentions. Tourism Management, 28(3), 703-713. https://doi.org/10.1016/j.tourman.2006.04.025

Yuksel, A., Yuksel, F., \& Bilim, Y. (2010). Destination attachment: Effects on customer satisfaction and cognitive, affective and connative loyalty. Tourism Management, 31(2), 274-284. https://doi.org/10.1016/j.tourman.2009.03.007

Zhang, H., Fu, X., Cai, L.A., \& Lu, L. (2014). Destination image and tourist loyalty: A meta-analysis. Tourism Management, 40, 213 223. https://doi.org/10.1016/j.tourman.2013.06.006

*** WAZA (2005). Building a Future for Wildlife - The World Zoo and Aquarium Strategy. World Association of Zoos and Aquariums, Bern, Switzerland. 